\title{
New promising variety of tobacco of Ukrainian selection - Berlei 46
}

\author{
Bialkovska H. ${ }^{1}$, Yurechko A. ${ }^{2}$, Velhan Ye. ${ }^{3}$, Pashchenko V. ${ }^{4}$ \\ Ternopil State Agricultural Experimental Station of the Institute of Forage and Agriculture of Podillia of the \\ NAAS \\ 12 Troleibusna Str., Ternopil, 46027, Ukraine \\ e-mail: udst_tiapv@ukr.net \\ ORCID: ${ }^{1} 0000-0002-9006-7393,{ }^{2} 0000-0003-2081-1516,{ }^{3} 0000-0001-9094-7641,{ }^{4} 0000-0002-8303-9386$
}

Goal. To substantiate the biological and chemical properties, production technology, and economic efficiency of a new promising variety of tobacco Berlei 46 with high resistance to biotic and abiotic factors and good quality of raw materials. Methods. General scientific and special: field, laboratory, selection with the use of induction apomixis, calculation, mathematical-statistical. Laboratory method was used for the determination of the chemical composition of raw tobacco. Apomixis was used in the selection of tobacco and helped to reduce that process on $4-6$ years, secured heterosis, identified new and rare micro-features in tobacco, as well as the use of mutants with valuable features in form of the valuable source material. Use of the calculation and mathematical-statistical methods determined economic efficiency of cultivation of new varieties of tobacco Berlei 46 and its advantages over the sort-standard Berlei 38, listed in the State register of plant varieties of Ukraine in 2001. Results. They substantiated biometric, chemical, and economic indices of the new high-yielding variety of tobacco Berlei 46 , which was selected by the method of individual selection in populations of intervarietal hybrids Berlei PolishxBanat. Conclusions. A new promising variety of tobacco Berlei 46, listed in the State register of plant varieties of Ukraine in 2017, has significant advantages for biological and productive signs over other varieties (resistant against diseases and pests, stressful weather conditions, high productivity, and quality of raw materials). The main advantage of the new variety Berlei 46 over sort-standard Berlei 38 is the high productivity — up to $31.6 \mathrm{t} / \mathrm{ha}$, marketable quality of raw material - output of top commercial varieties is $90-95 \%$, and the content of nicotine $-2.01-2.13 \%$. Berlei 46 is recommended for cultivation in tobacco farms of the Forest-Steppe zone of Ukraine.

Key words: sort-standard, apomixis, yield, nicotine, proteins, carbohydrates, profitability.

DOI: https://doi.org/10.31073/agrovisnyk202005-05

The functioning of the agricultural sector of the economy in market conditions requires new approaches to the scientific support of agricultural production. Basic research in the field of tobacco growing is becoming relevant: the creation of new and improvement of existing varieties and hybrids of tobacco Nisotiana tabacum $L$. Particular attention is paid to accelerating and improving the selection process in their creation.

For the last 50 years, selection studies have aimed at creating varieties with a low nicotine content and a thin central vein of the leaf with a minimum nicotine content $(0.01 \%)$. With the advent of the "broken vein" method in cigarette production technology, which allows it to be processed and uses in the manufacture of tobacco products, varieties with high nicotine content $(2.0-2.5 \%)$ began to be in demand.

One of the varieties of tobacco that can provide this type of raw material is a new variety Berley 46 , bred by breeders of the Scientific and Technological Department of Tobacco Ternopil State Agricultural Research Station of the Institute of Feed and Agriculture Podillia NAAS and entered in the State Register of Plant Varieties of Ukraine in 2017. The variety has significant advantages in terms of biological and economic value over other varieties (resistance to diseases and pests, stressful weather conditions, high yield and quality of raw materials).

Analysis of recent research and publications. The need for continuous creation and introduction of new tobacco varieties is due to many factors: aging of the variety, the emergence of new diseases and pests, new technologies in the processing industry, expanding the area of cultivation, increasing consumer demands for product quality and others. During the previous years of research, many varieties have created in the Ukrainian Tobacco Research Station, which ceased to meet the requirements of production in terms of productivity and technological quality of raw materials and lost their competitiveness in the tobacco market of Ukraine over time. There is a need to create new varieties and hybrids of tobacco with valuable economic indicators, environmental adaptability, disease resistance and quality chemical composition [1].

Production of tobacco and seeds are basic for the development of tobacco production. Intensification of the selection process offers the development of genetic bases of selection, which means the study of the structure of variability of selection traits in the source material and the development of genetically sound selection methods [2]. Therefore the selection of tobacco in the scientific and technological department directed at creation of early and medium-ripe varieties and hybrids with high potential of plants productivity $(25-35 \mathrm{~kg} / \mathrm{ha})$, that increase resistance to disease, high yield of higher commodity varieties $(80-95 \%)$ and the optimal chemical composition of raw materials (nicotine content $-1.2-2.5 \%$, carbohydrates $-5 \%$ or more, and low protein content - less than $5 \%$ ).

The most significant achievements in the field of tobacco breeding and determination of resistance of tobacco varieties and hybrids to diseases and pests in Ukraine belong to scientists Sarychev Yu.F. [2], 
Pashchenko I.N. [3], Saviniy OI, Matiega O.O. etc. [4-7]. Scientists of the All-Russian Research Institute of Tobacco, Shag and Tobacco Products deal with the problems of the tobacco industry in the Russian Federation [8].

Purpose. To substantiate the biological and chemical properties of a new promising tobacco variety Berley 46 , which has high resistance to biotic and abiotic factors, environmental adaptability and quality of raw materials, cultivation technology and economic efficiency indicators.

Materials and methods of research. Scientific research of gray podzolic soils, conducted in the southern agroclimatic region of the Transnistrian zone of Ukraine, explore the containing humus $1.6 \%$, mobile phosphorus 1.68, potassium $10.2 \mathrm{mg}$ per $100 \mathrm{~g}$ of soil, $\mathrm{pH}$ 5.6, in the field № 1 seven-field scientific crop rotation of the scientific and technological department of tobacco production of the Ternopil State Agricultural Research Station of the Institute of Feed and Agriculture of Podillia NAAS.

Weather conditions in the years of research (2016-2018) differed from long-term averages, which allowed us to study and compare the reaction of a new variety of tobacco Burley 46 in the dry 2016 and in more favorable 2017-2018.

Weather conditions in 2016 marked by abnormally low rainfall. The growing season lasted 183 days. The sum of active temperatures for this period was $3237.2^{\circ} \mathrm{C}$ (norm $2800^{\circ} \mathrm{C}$ ), dropped $75.7 \mathrm{~mm}$ at a rate of $370-$ $420 \mathrm{~mm}$. According to the hydrothermal coefficient (SCC), the vegetation period of 2016 characterized as very arid: $\mathrm{SCC}=0.2$. Adverse weather conditions of the growing season (lack of moisture and high average daily air temperature) negatively affected the growth and development of tobacco plants.

Weather conditions in 2017 and 2018 contributed to the normal growth and development of tobacco plants in the seedling and field periods. In 2017, the growing season lasted 180 days. The sum of active temperatures during this period was $4002^{\circ} \mathrm{C}$ (norm $2800^{\circ} \mathrm{C}$ ), $216.3 \mathrm{~mm}$ fell at the norm $370-420 \mathrm{~mm}$. According to the hydrothermal coefficient (SCC), the vegetation period of 2017 characterized as arid: SCC = 0.5 .

In 2018, the growing season began on April 5 and lasted 170 days. The sum of active temperatures during this period was $3118^{\circ} \mathrm{C}$ (norm $2800^{\circ} \mathrm{C}$ ), $338.9 \mathrm{~mm}$ of precipitation fell at norm $370-420 \mathrm{~mm}$. According to the hydrothermal coefficient (SCC), the vegetation period of 2018 characterized as sufficiently wet: $\mathrm{SCC}=1.08$.

Scientific basic research conducted in the field and laboratory conditions according to generally accepted methods [9].

The main method of selection work is hybridization by simple, complex and saturating crosses with subsequent individual and linear selection of optimal phenotypes in generations of intraspecific hybrids. The selection process using induction apomixis performed according to the method of Sarychev Yu.F. (1984) and Savina O.I. (2004). Evaluation of cultivars performed on morphological and biological characteristics according to the classifier Semenova Ya.V. (1982). Selection of related pairs during selection for heterosis performed according to the method of Gulyaev GV (1978).

The percentage of nicotine, carbohydrates and proteins was determined in dried tobacco leaves: nicotine - by the Keller method (removal of nicotine and its salts using kerosene, 1968), carbohydrates - by the Bertrand method (extraction carbohydrates from tobacco raw water, 1968), proteins - Bernstein method (with the basic salt of sulfate copper proteins precipitate), then they are burned by the Kjeldahl method, 1968). The quality assessment of tobacco raw materials (assortment) performed according to GOST 807378. Mathematical data processing performed according to the method of Dospekhov B.A. [10].

Research results and their discussion. A specific function of selection in tobacco growing is the creation of new varieties and hybrids of tobacco to increase production and improve the quality of grown products.

Breeding varieties of domestic and foreign breeding are valuable starting material. They can be uses for mass or individual selection of new forms, as well as for creating hybrid populations. Particularly valuable breeding varieties of tobacco are often use as donors of individual traits (plant height, number of leaves, immunity to diseases and pests, nicotine content, etc.).

The tobacco variety Berley 46 was bred by individual selection in populations of intervarietal hybrids of Berley Polish $x$ Banat [11]. In the selection of pairs for crossing, the biological features of the original varieties and the nature of inheritance of these features by hybrids F1 and F2 (dominant, recessive, intermediate heredity) were carefully studied the day before. Tobacco variety Burley Polish foreign breeding dominates by high nicotine content and yellow leaf color, and in the Banat tobacco dominant is the height of the main stem and immunity to diseases and pests.

As a result, of many years of work of breeders, a new promising variety of tobacco Berley 46 have been created, which turned out to be much better than the variety - the Burley 38 standard, registered in 2001. The habit of the plant is conical. Raw skeletal type. It characterizes by close maturation of leaves in tiers. The leaf is broadly elliptical, the shape of the apex is moderately pointed. Resistant to adverse soil and climatic conditions, has a complex resistance to diseases: downy mildew, bronze tomatoes, white feverfew and bacterial ripples, suitable for safety technology of cultivation. 


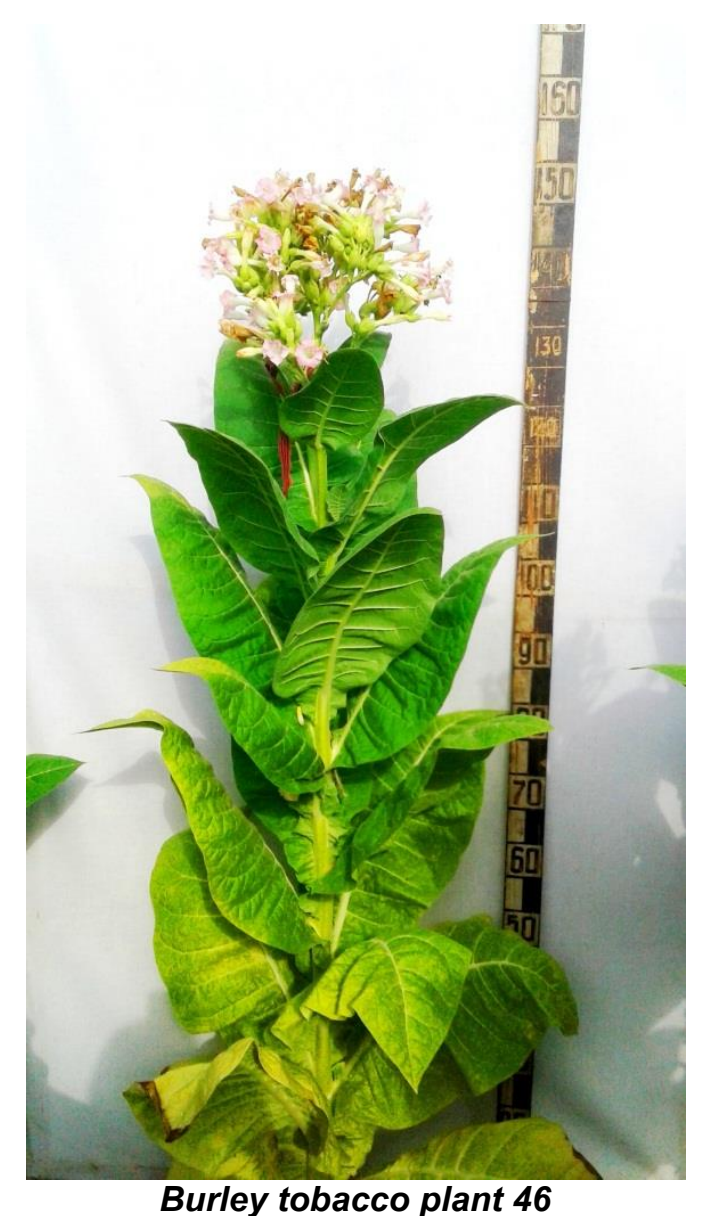

Components and features of Burley 46 tobacco technology: predecessor - winter wheat, deep fallow plowing at $27-30 \mathrm{~cm}$, planting scheme $70 \times 40 \mathrm{~cm}$, fertilizer $-\mathrm{N}_{60} \mathrm{P}_{90} \mathrm{~K}_{120}$, planting dates - the first or second decade of May, harvesting in three steps (instead of $4-5$, as provided by conventional technology), drying of leaves in natural conditions (film greenhouses, attics). Table 1 shows the biometric indicators of the variety Burley 46 in comparison with the standard.

1. Biometric Indicators and yields of new variety of tobacco Burley $462016-2018$ years

\begin{tabular}{|c|c|c|c|c|c|c|}
\hline \multirow[b]{2}{*}{ Sort } & \multirow{2}{*}{$\begin{array}{l}\text { Height } \\
\text { plants, } \\
\text { cen. }\end{array}$} & \multirow{2}{*}{$\begin{array}{c}\text { Number } \\
\text { of technical } \\
\text { leaves, } \\
\text { pieces }\end{array}$} & \multicolumn{2}{|c|}{ Leaf leaves, cen. } & \multicolumn{2}{|c|}{ Yield, h/ha, } \\
\hline & & & length & width & actually & $\begin{array}{l}+,- \text { to the } \\
\text { standard }\end{array}$ \\
\hline \multicolumn{7}{|c|}{$2016 \mathrm{y}}$. \\
\hline $\begin{array}{l}\text { Burley } 38 \\
\text { (standard) }\end{array}$ & 96 & 18 & 31 & 22 & 15,2 & - \\
\hline Burley 46 & 98 & 19 & 36 & 25 & 23,5 & $+8,3$ \\
\hline \multicolumn{7}{|c|}{2017 y. } \\
\hline $\begin{array}{c}\text { Burley } 38 \\
\text { (standard) }\end{array}$ & 120 & 20 & 35 & 25 & 19,4 & - \\
\hline Burley 46 & 157 & 22 & 45 & 28 & 35,7 & $+16,3$ \\
\hline \multicolumn{7}{|c|}{2018 y. } \\
\hline $\begin{array}{l}\text { Burley } 38 \\
\text { (standard) }\end{array}$ & 155 & 22 & 34 & 26 & 29,8 & - \\
\hline Burley 46 & 163 & 23 & 48 & 29 & 35,6 & $+5,8$ \\
\hline \multicolumn{7}{|c|}{ Average indicators for 2016-2018 yy. } \\
\hline $\begin{array}{c}\text { Burley } 38 \\
\text { (standard) }\end{array}$ & 124 & 20 & 33 & 24 & 21,5 & - \\
\hline Burley 46 & 139 & 21 & 43 & 27 & 31,6 & 10,1 \\
\hline
\end{tabular}

$\mathrm{HIP}_{05}-10.14 \mathrm{~h} / \mathrm{ha}$

In the climatic conditions of 2017-2018, the closest to the norm in the region, the height of the main stem of the plant was equal to $157-163 \mathrm{~cm}$, the size of the leaf blade respectively $45 \times 32 \mathrm{~cm}$ and $48 \times 29 \mathrm{~cm}$, the number of technically ripe leaves - 22-23, the color of the mature leaf in the field of light- green, and dried raw materials - light brown. The yield of tobacco variety Berley 46 , in the dry 2016 , was $23.5 \mathrm{~kg} / \mathrm{ha}$, which is $8.3 \mathrm{~kg} / \mathrm{ha}$ higher than the standard variety Burley 38 . The main reason for low yields is the influence of 
abiotic factors: lack of moisture and high air temperature during the growing season. In 2017-2018, the yield was 35.7 and $35.6 \mathrm{c} / \mathrm{ha}$, respectively, which is $5.8-16.3 \mathrm{c} / \mathrm{ha}$ higher than the standard (fig.).

The quality of raw tobacco depends on its chemical composition. Tobacco feed contains more than 70 different substances, but only basic indicators use for evaluation - nicotine, carbohydrates and protein substances [12, 13].

As a result of studies to determine the marketable quality of raw materials, the materiality of tobacco leaves, as well as the content of nicotine, carbohydrates and proteins in dry tobacco leaves, the following indicators has obtained, that show in table 2.

2. Quality indicators of tobacco raw materials of variety Burley 46 for $2016-2018$ years

\begin{tabular}{|c|c|c|c|c|c|c|c|c|c|c|}
\hline \multirow[b]{2}{*}{ Sort } & \multicolumn{2}{|c|}{$\begin{array}{c}\text { Product } \\
\text { range } \\
\text { I-II } \\
\text { grade, } \% \\
\end{array}$} & \multicolumn{2}{|c|}{$\begin{array}{l}\text { Materiality, } \\
\text { gr/cen. }{ }^{2}\end{array}$} & \multicolumn{6}{|c|}{ Chemical composition, content in \% } \\
\hline & 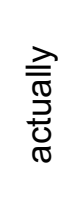 & 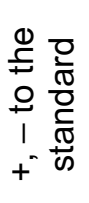 & 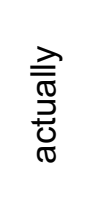 & 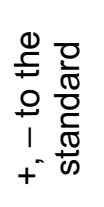 & $\begin{array}{l}\frac{0}{\frac{c}{0}} \\
\frac{0}{0} \\
\frac{0}{2}\end{array}$ & 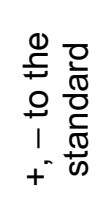 & 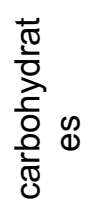 & $\begin{array}{l}0 \\
\stackrel{0}{5} \frac{0}{\pi} \\
0 \\
0 \\
1 \\
1 \\
+\frac{\pi}{0} \\
+\infty\end{array}$ & 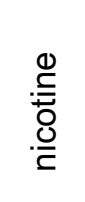 & 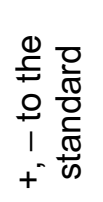 \\
\hline \multicolumn{11}{|c|}{$2016 \mathrm{y}}$. \\
\hline $\begin{array}{l}\text { Burley } 38 \\
\text { (standard) }\end{array}$ & $5^{8}$ & - & $\begin{array}{l}0 \\
66\end{array}$ & - & 90 & - & $\begin{array}{r}1 \\
, 10^{1} \\
\end{array}$ & - & $9^{1,}$ & - \\
\hline Burley 46 & $0^{9}$ & +5 & $\begin{array}{l}0, \\
68\end{array}$ & $\begin{array}{l}+0, \\
02\end{array}$ & $\begin{array}{r}5, \\
21\end{array}$ & $1,6 \overline{-}$ & $\begin{array}{r}1 \\
, 18^{1} \\
\end{array}$ & $\begin{array}{l}+0, \\
08 \\
\end{array}$ & $\begin{array}{l}2, \\
01\end{array}$ & $\begin{array}{l}+0,0 \\
5\end{array}$ \\
\hline \multicolumn{11}{|c|}{2017 y. } \\
\hline $\begin{array}{c}\text { Burley } 38 \\
\text { (standard) }\end{array}$ & $5^{8}$ & - & $\begin{array}{l}0, \\
39\end{array}$ & - & $\begin{array}{c}6, \\
28 \\
\end{array}$ & - & $\begin{array}{r}1 \\
, 84 \\
\end{array}$ & - & ${ }^{1}$, & - \\
\hline Burley 46 & $2^{9}$ & +7 & $\begin{array}{l}0, \\
47\end{array}$ & $\begin{array}{l}+0, \\
08\end{array}$ & $\begin{array}{r}5, \\
81\end{array}$ & $0,4 \overline{-}$ & $\begin{array}{r}1 \\
, 12 \\
\end{array}$ & $0,7 \overline{2}$ & 2 , & $\begin{array}{l}+0,2 \\
8\end{array}$ \\
\hline \multicolumn{11}{|c|}{$2018 \mathrm{y}}$. \\
\hline $\begin{array}{c}\text { Burley } 38 \\
\text { (standard) }\end{array}$ & $7^{8}$ & - & $\begin{array}{l}0 \\
44\end{array}$ & - & 9, & - & $\begin{array}{r}1 \\
, 75^{1}\end{array}$ & - & $\begin{array}{l}1, \\
78\end{array}$ & - \\
\hline Burley 46 & $5^{9}$ & +8 & $\begin{array}{c}0 \\
57\end{array}$ & $\begin{array}{c}+0 \\
13 \\
\end{array}$ & $\begin{array}{r}5, \\
26 \\
\end{array}$ & $\begin{array}{r}- \\
1,68 \\
\end{array}$ & $\begin{array}{r}1 \\
, 04 \\
\end{array}$ & $0, \overline{1}$ & $1^{2,}$ & $\begin{array}{l}+0,3 \\
5\end{array}$ \\
\hline \multicolumn{11}{|c|}{ Average indicators for 2016-2018 yy. } \\
\hline $\begin{array}{c}\text { Burley } 38 \\
\text { (standard) }\end{array}$ & $6^{8}$ & - & $5^{0}$ & - & $\begin{array}{r}6, \\
71\end{array}$ & - & $\begin{array}{r}1 \\
, 56 \\
\end{array}$ & - & $8^{1,}$ & - \\
\hline Burley 46 & $2^{9}$ & +6 & $\begin{array}{r}0 \\
57\end{array}$ & $7^{+0}$ & $\begin{array}{r}5, \\
43\end{array}$ & 1,28 & $\begin{array}{r}1 \\
, 11 \\
\end{array}$ & $\begin{array}{r}- \\
0,45 \\
\end{array}$ & ${ }^{2,}$ & $+0,2$ \\
\hline
\end{tabular}

Tobacco raw materials of the Burley 46 grade are of high quality - the yield of higher commodity grades is $90-95 \%$, which is $5-8 \%$ higher than the standard, materiality $-0.47-0.67 \mathrm{gr} / \mathrm{cen} .{ }^{2}$. Tobacco raw materials with a nicotine content of $2 \%$ and above have considered high-nicotine and such raw materials needed by cigarette factories at this technological stage of manufacturing tobacco products. The nicotine content in the dry leaf of Burley 46 tobacco is $2.01-2.19 \%$. The Burley 46 variety outperforms the Burley 38 standard variety in almost all characteristics.

The technological projects developed by the scientists of the tobacco department provide a clear sequence of all types of work, starting with soil preparation and laying greenhouses for growing tobacco seedlings and ending with harvesting and post-harvest processing, the physical volume of each type of work, composition units, their service personnel, production rates and the number of norm-changes. Annually, on the basic of technological maps, the normative indicators of production cost of tobacco raw materials are determined taking into account the level of the minimum wage and prices for inventory [14].

The substantiation of indicators of economic efficiency of cultivation of tobacco of the Berley 46 grade during 2016-2018 has defined and carried out (tab. 3).

3. Economic efficiency of growing Burley 46 tobacco for 2016-2018 years

\begin{tabular}{|c|c|c|c|c|c|c|c|}
\hline Sort & $\begin{array}{l}\text { Yiel } \\
\text { d, } \\
\mathrm{h} / \mathrm{ha},\end{array}$ & $\begin{array}{l}\text { Co } \\
\text { st } \\
1 \mathrm{~h}, \\
\cup A \\
\mathrm{H}\end{array}$ & $\begin{array}{c}\text { Total } \\
\text { cost, UAH } \\
\text { /ha }\end{array}$ & $\begin{array}{r}\text { Receip } \\
\text { ts UAH/ha }\end{array}$ & $\begin{array}{l}\text { Pro } \\
\text { fit, } \\
\text { UAH } \\
\text { /ha }\end{array}$ & $\begin{array}{c}\text { Profit } \\
\text { a-bility, } \\
\%\end{array}$ & $\begin{array}{l}+,- \text { to } \\
\text { the } \\
\text { stand } \\
\text { ard, } \%\end{array}$ \\
\hline \multicolumn{8}{|l|}{2016 y. } \\
\hline Burley 38 (standard) & $2^{15}$ & $\begin{array}{l}286 \\
0\end{array}$ & 43472 & 60800 & $\begin{array}{c}173 \\
28\end{array}$ & 39,9 & - \\
\hline
\end{tabular}




\begin{tabular}{|c|c|c|c|c|c|c|c|}
\hline Burley 46 & $\begin{array}{l}23, \\
5\end{array}$ & $\begin{array}{l}257 \\
0\end{array}$ & 60395 & 94000 & $\begin{array}{l}336 \\
05\end{array}$ & 55,6 & $+15,7$ \\
\hline \multicolumn{8}{|l|}{2017 y. } \\
\hline Burley 38 (standard) & $4^{19}$ & $\begin{array}{l}502 \\
0\end{array}$ & 97388 & $\begin{array}{c}11640 \\
0\end{array}$ & $\begin{array}{l}190 \\
12\end{array}$ & 19,5 & - \\
\hline Burley 46 & $\begin{array}{l}35, \\
7\end{array}$ & $\begin{array}{l}433 \\
0 \\
\end{array}$ & $\begin{array}{c}15458 \\
1\end{array}$ & $\begin{array}{c}21420 \\
0\end{array}$ & $\begin{array}{c}596 \\
19\end{array}$ & 38,6 & $+19,1$ \\
\hline \multicolumn{8}{|l|}{$2018 \mathrm{y}}$. \\
\hline Burley 38 (standard) & $\begin{array}{l}29, \\
8\end{array}$ & $\begin{array}{l}4999 \\
0 \\
\end{array}$ & $\begin{array}{c}14870 \\
2\end{array}$ & $\begin{array}{l}17880 \\
0\end{array}$ & $\begin{array}{l}300 \\
98\end{array}$ & 20,2 & - \\
\hline Burley 46 & $\begin{array}{l}35, \\
6\end{array}$ & $\begin{array}{l}489 \\
0\end{array}$ & $\begin{array}{c}17408 \\
4\end{array}$ & $\begin{array}{l}21360 \\
0\end{array}$ & $\begin{array}{c}395 \\
16\end{array}$ & 22,7 & $+2,5$ \\
\hline
\end{tabular}

Production of Burley 46 tobacco raw materials characterized by better economic indicators than Burley 38. In 2016, the level of profitability was 39.9 and $55.6 \%$, respectively, which is $15.7 \%$ more than the standard variety. The decrease in profitability in 2017-2018 was caused by a significant increase in the minimum wage, as the cost of tobacco as a labor-intensive crop increased. In the structure of tobacco production costs, the largest share occupied by wage costs $73.0 \%$ and accruals $-14.2 \%$, material costs are $12.8 \%$. The level of profitability of Burley 46 tobacco production in 2018 was $22.7 \%$, which is $2.5 \%$ higher than the standard.

\section{Conclusions}

The new promising tobacco variety Berley 46, entered in the State Register of Plant Varieties of Ukraine in 2017, has significant advantages in biological and economic value over other varieties (resistance to diseases and pests, stressful weather conditions, high yields and quality of raw materials).

The main advantage of the new variety Burley 46 over the standard Burley 38, is a high average yield of $31.6 \mathrm{~kg} / \mathrm{ha}$ due to the number of leaves and large leaf blade size, good marketable quality and chemical composition of raw materials (nicotine content $-2.08 \%$, protein $-5.43 \%$ and carbohydrates $-1.11 \%$ ). Tobacco variety Berley 46 has recommended for cultivation in tobacco-bearing farms of the Forest-Steppe zone of Ukraine.

\section{References}

1. Bialkovska, H. D., \& Yurechko, A. A. (2014). Nasinnytstvo tiutiunu v umovakh rynku [Tobacco seeds in market conditions]. Sustainable development of economy, 3(25), 156-161. [In Ukrainian].

2. Sarychev, Yu. F. (1986). Novyy sposob polucheniya indutsirovannogo diploidnogo apomiksisa u N. Tabacum L. [A new method for producing induced diploid apomixis in N. Tabacum L.]. Genetics, 7, 11381142. [In Russian].

3. Pashchenko, I. M., \& Pashchenko, V. I. (2010). Selektsiia stiikykh sortiv tiutiunu yak osnovnyi metod zakhystu vid shkidlyvykh orhanizmiv [Selection of resistant varieties of tobacco as the main method of protection against pests]. Perspektyvni napriamy rozvytku haluzei APK i pidvyshchennia efektyvnosti naukovoho zabezpechennia ahropromyslovoho vyrobnytstva [Perspective directions of the field of agriculture and improve the efficiency of research providing agricultural production]. II Vseukr. nauk.-prakt. konf. mol. vchenykh: tezy dop. [Collection of theses of scientific lectures Proceedings of the Second All-Ukrainian scientific-practical conference Young Scientists]. Ternopil, Ukraine. (pp. 92-93). [In Ukrainian].

4. Savina, O. I., Roik, M. V., \& Belohorodska-Cherednychok, S. P. (2002). Apomiksys $\vee$ tiutiunu [Apomixis in tobacco]. Bulletin of Agricultural Science, 9, 40-43. [In Ukrainian].

5. Savina, O. I., Matiieha, O. O., Sheidyk, K. A., \& Korsak, V. V. (2010). Formuvannia navchalnoi kolektsii tiutiunu [Formation of educational collection of tobacco]. Plant Genetic Resources, 8, 58-63. [In Ukrainian].

6. Savina, O. I., Sheidyk, K. A., Korsak, V. V., \& Matiieha, O. O. (2009). Rozshyrennia potentsialu selektsiinoho materialu tiutiunu iz zastosuvanniam apomiksysu [Expanding the potential of tobacco breeding material using apomixis]. Collection of scientific works of the National Scientific Center "Institute of Agriculture of NAAS", 3, 143-152. [In Ukrainian].

7. Savina, O. I., Matiieha, O. O., Sheidyk, K. A., Korsak, V. V., \& Lovas V. P. (2011). Selektsiina tsinnist vykhidnoho materialu tiutiunu za osnovnymy oznakamy [Selection value of the source material of tobacco according to the main features]. Bulletin of Agricultural Science, 9, 34-36. [In Ukrainian].

8. Pavlyuk, I. V., Zhigalkina, G. N., \& Ivanitskiy, K. I. (2016). Itogi sortoispytaniy novykh sortov tabaka v 2015 godu [The results of the variety trials of new varieties of tobacco in 2015]. Collection of scientific works of the all - Russian scientific research institute of tobacco, makhorka and tobacco products, 181, 263-273. [In Russian].

9. Kosmodemyanskiy, V. N., Psareva, Ye. N., Grebenkin, A. P., Yakovuk, A. S., Vlasov, V. I., Ivanova, T. Z., \& Ruban, E. V. (1974). Metodiki selektsionnoy raboty po tabaku i makhorke [Methodologies of selection work on tobacco and makhorka]. Krasnodar. [In Russian].

10. Dospekhov, B. A. (1985). Metodika polevogo opyta [Method for field experiment]. Moscow: Agropromizdat. [In Russian].

11. Bialkovska, H. D., Yurechko, A. A., Pashchenko, V. I., \& Velhan, Ye. L. (2016). Innovatsiine zabezpechennia haluzi tiutiunnytstva [Innovative provision of the tobacco industry]. Likarski roslyny: tradytsii 
ta perspektyvy doslidzhen [Medicinal plants: traditions and prospects for research]. III Mizhnarod. nauk. konf., prysviachena 100-richchiu Dosl. stantsii likar. roslyn, DSLR IAP NAAN [3 Int. scientific conference dedicated to the 100th anniversary of the Experimental Station of Medicinal Plants]. (pp. 263-267). Kyiv: "DIA". [In Ukrainian].

12. Jassbi, A. R., Zare, S., Asadollahi, M., \& Schuman, M. C. (2017). Ecological Roles and Biological Activities of Specialized Metabolites from the Genus Nicotiana. Chemical Reviews, 117(19), 12227-12280. doi: 10.1021/acs.chemrev.7b00001.

13. Walton, N. J., Alfermann, A. W., \& Rhodes, M. J. C. (2018). Production of Secondary Metabolites in Cell and Differentiated Organ Cultures. Annual Plant Reviews book series, 318-352. DOI:10.1002/9781119312994.apr0024.

14. Bialkovska, H. D., Pashchenko, V. I., Havriliuk, O. S., \& Velhan, Ye. L. (2018). Naukovo praktychni rekomendatsii $z$ vyroshchuvannia tiutiunu $v$ Prydnistrovskomu rehioni [Scientific and practical recommendations for growing tobacco in the Transnistrian region]. Ternopil: TSDSGDS IKSGP NAAS. [In Ukrainian]. 